УДК 677.055.32:677.072

https://doi.org/10.35546/kntu2078-4481.2020.1.1.9

О.М. ДМИТРИК

Київський національний університет технологій та дизайну

B.I. БEЗСМЕРТНА

Київський національний університет технологій та дизайну ORCID: 0000-0002-2247-6718

Л.Є. ГАЛАВСЬКА

Київський національний університет технологій та дизайну ORCID: 0000-0002-6994-6641

\title{
ВПЛИВ ТИПУ В'ЯЗАЛЬНОГО ОБЛАДНАННЯ НА ПОКАЗНИКИ ВТРАТИ МІЦНОСТІ ПОЛІЕТИЛЕНОВИХ ТА ПАРААРАМІДНИХ НИТОК ПІСЛЯ В'ЯЗАННЯ
}

У даній статті представлено результати дослідження впливу типу плосков'язального обладнання на показники втрати міцності високомолекулярних поліетиленових (ПЕ) та параарамідних (ПА) ниток після в'язання, а також у разі їх поєднання у проиесі в'язання з металевою монониткою. Зразки трикотажних полотен вироблено переплетенням кулірна гладь на двох типах плосков'язального обладнання 8 класу: плоскофангова машина типу ПВРК та рукавичковий автомат ПА-8-33 (РА).

У відповідності до існуючої методики встановлено величину розривального навантаження та видовження ниток до та після в'язання на розривній машині КаоТіеһ КT-7010AZ. Для оцінки втрати міџності нитки після в'язання використано коефіцієнт використання міцності, який представляє собою відношення міџності нитки після в'язання до ї̈ вихідної міџності.

У результаті реалізованого експерименту виявлено вищі значення коефіцієнта використання міцності ПА нитки порівняно з ПЕ. На втрату міиності ПЕ ниток впливає вв'язування у структуру трикотажу металевої мононитки. Таким чином ПЕ нитки при переробиі їх у структуру трикотажу переплетення гладь у більшій мірі втрачають міџність, щуо пояснюється особливостями вихідного полімера. ПЕ нитки більш чутливі до видовження при силових навантаженнях та руйнації окремих волокон внаслідок взаємодії з металевою монониткою. Це і спричиняє більшу втрату міцності у процесі в'язання трикотажу саме ПЕ нитки, яка за своєю будовою є багатофіламентною некрученою ниткою.

Одержані у ході досліджень характеристики втрати міџності високомолекулярних поліетиленових та параарамідних ниток, перероблених у структуру кулірного трикотажу переплетення гладь, дають можливість формувати задані властивості трикотажу у кінцевому продукті.

Ключові слова: розривальне навантаження, розривальне видовження, коефіцієнт використання міцності, втрата міцності, нитки підвищеної міџності,, високомолекулярна поліетиленова нитка, параарамідна нитка, металева мононитка.

О.М. ДМЫТРЫК

Киевский национальный университет технологий и дизайна

В.И. БЕССМЕРТНАЯ

Киевский национальный университет технологий и дизайна ORCID: 0000-0002-2247-6718

Л.Е. ГАЛАВСКАЯ

Киевский национальный университет технологий и дизайна ORCID: 0000-0002-6994-6641

\section{ВЛИЯНИЕ ТИПА ВЯЗАЛЬНОГО ОБОРУДОВАНИЯ НА ПОКАЗАТЕЛИ ПОТЕРИ ПРОЧНОСТИ ПОЛИЭТИЛЕНОВЫХ И ПАРААРАМИДНИХ НИТЕЙ ПОСЛЕ ВЯЗАНИЯ}

В данной статье представлень результаты исследования влияния типа плосковязального оборудования на показатели потери прочности высокомолекулярных полиэтиленовых (ПЭ) $и$ параарамидных (ПА) нитей после вязания, а также в случае их сочетания в прочессе вязания с металлической мононитью. Образцы трикотажных полотен изготовлены переплетением кулирная гладь на двух типах плосковязального оборудования 8 класса: плоскофанговой машине типа ПВРК и перчаточном автомате ПА-8-33 (РА).

В соответствии с существующей методикой установлено величину разрывной нагрузки $и$ удлинения нитей до и после вязания на разрывной машине КаоТіеһ KT-7010AZ. Для оиенки потери 
прочности нити после вязания использован коэффициент использования прочности, который представляет собой отночение прочности нити после и до вязания.

В результате реализованного эксперимента выявлено более высокие значения коэффициента использования прочности ПА нити по сравнению с ПЭ. На потерю прочности ПЭ нитей влияет ввязывание в структуру трикотажа металлической мононити. Таким образом ПЭ нити при переработке их в структуру трикотажа переплетения гладь в большей степени теряют прочность, что объясняется особенностями исходного полимера. ПЭ нити более чувствительны к удлинению при силовых нагрузках и разрушению отдельных волокон в результате взаимодействия с металлической мононитью. Это и вызывает большую потерю прочности в процессе вязания трикотажа именно ПЭ нитей, которые по своему строению являются багатофиламентными некручеными нитями.

Полученные в ходе исследований характеристики потери прочности высокомолекулярных полиэтиленовых и параарамидных нитей, переработанных в структуру кулирного трикотажа переплетения гладь, дают возможность формировать заданные свойства трикотажа в конечном продукте.

Ключевые слова: разрывная нагрузка, разрывное удлинение, коэффициент использования прочности, потеря прочности, нити повышенной прочности, высокомолекулярная полиэтиленовая нить, параарамидная нить, металлическая мононить.

O.M. DMYTRYK

Kyiv National University of Technology and Design

V.I. BEZSMERTNA

Kyiv National University of Technology and Design

ORCID: 0000-0002-2247-6718

L.Ye. HALAVSKA

Kyiv National University of Technology and Design

ORCID: 0000-0002-6994-6641

\section{THE INFLUENCE OF THE TYPE OF KNITTING EQUIPMENT ON THE STRENGTHS OF LOSSING STRENGTH OF POLYETHYLENE AND PARARAMID THREADS AFTER KNITTING}

This article presents the results of a study of the effect of type of knitting equipment on the loss of strength of high molecular weight polyethylene (PE) and para-aramid (PA) filaments after knitting, as well as when combined in the process of knitting with a metal monofilament. Samples of knitted fabrics are made by interlacing the cooling surface on two types of flat-knitting equipment of the 8th class: the flat-type machine $P V R K$ and the glove machine PA-8-33 (RA).

In accordance with the existing methodology, the value of the breaking load and the elongation of the yarns before and after knitting on the KaoTieh KT-7010AZ breaking machine was established. To estimate the loss of thread strength after knitting, the use factor of strength, which is the ratio of the strength of the thread after and before knitting, was used.

As a result of the experiment, it is found that the coefficient of PA strength of the yarn of knitwear samples without introduction into the metal monofilament structure, in comparison with PE, increases regardless of the type of knitting equipment. When introduced into the structure of a metal monofilament, regardless of the type of knitting equipment, the coefficient of PA strength of the filament compared to the PE increases. Thus, the PE filaments, when processing them into the structure of knitwear, weave loosening, to a greater extent, lose their strength, which is explained by the peculiarities of the original polymer. PE filaments are more sensitive to elongation at power loads and destruction of individual fibers due to interaction with the metal monofilament. This causes a greater loss of strength in the knitting process of the PE thread itself, which by its structure is a multifilament non-twisted thread.

The characteristics of the loss of strength of high-molecular-weight polyethylene and para-aramid threads obtained in the structure of the knit fabric knit fabric, obtained in the course of the researches, give the opportunity to form the specified properties of knitwear in the final product.

Keywords: tensile load, tensile elongation, strength factor, loss of strength, high strength raw material, high molecular weight polyethylene filament, para-aramid filament, metallic monofilament.

\section{Постановка проблеми}

Останнім часом зростає попит на текстильні матеріали для потреб оборонно-промислового комплексу. Розширення сфер використання текстилю стало можливим завдяки появі сировини підвищеної міцності різноманітного походження: вуглецеві, скляні, керамічні, кварцеві, параарамідні та поліетиленові волокна й нитки. Зокрема нитки знайшли своє застосування у виробництві текстилю підвищеної міцності для виготовлення засобів індивідуального захисту від дії механічних ушкоджень. 
Вплив умов переробки надміцної сировини у текстильний матеріал, а саме вплив процесу в'язання та типу в'язального обладнання на зміну їх властивостей у даний час вивчено недостатньо. Наявна в літературних джерелах інформація не дає надійних відомостей при порівняльних випробуваннях ниток підвищеної міцності із застосуванням ідентичних методів, ускладнює зіставлення властивостей ниток й оптимізацію їх застосування [1-3].

Аналіз останніх досліджень і публікацій

Використання трикотажу технічного призначення 3 кожним роком зростає, що пов'язано 3 появою нових видів надміцної сировини та технологічних можливостей в'язального обладнання. Однак питання впливу властивостей сировини та особливостей протікання технологічних процесів виробництва на показники втрати їх міцності та фізико-механічні характеристики трикотажу вивчені недостатньо.

У роботі [4] автором завдяки реалізації повного двофакторного експерименту досліджено вплив глибини кулірування та натягу ниток на розривні характеристики трикотажу. Дослідні зразки трикотажу вироблені на двофонтурній плосков'язальній машині Stoll CMS 33010 класу з високомолекулярних поліетиленових ниток. Встановлено, що найбільший вплив на структурні характеристики трикотажу 3 двофонтурних плосков'язальних машин з наявністю платин має глибина кулірування та натяг нитки. Однак, автором роботи не проводилося дослідження втрати міцності самих ниток після в'язання.

Автором іншої роботи [5] шляхом проведення повного трифакторного активного експерименту встановлено регресійні залежності, що описують вплив параметрів в'язання на збереження міцності параарамідної нитки. Досліджено, що на величину розривального навантаження нитки після в'язання впливає лінійна густина, глибина кулірування та зусилля відтягування полотна, які діють на показники втрати міцності параарамідних ниток у процесі в'язання. Дослідні зразки вироблені на плосков'язальному обладнанні типу ПВРК. Тому одержані рівняння регресії не можуть бути використані у разі вироблення трикотажу на плосков'язальному обладнанні з використанням платин у процесі в'язання. У роботі не акцентується увага на особливостях самого процесу петлетворення, зокрема на загальному чи зосередженому зусиллі відтягування.

У роботі [6] автором на підставі порівняльного аналізу високомолекулярних поліетиленових та параарамідних ниток різних виробників представлено властивості волокон вихідної сировини. Наведені дослідження направлені на вивчення фізико-механічних характеристик тканих структур, вироблених 3 використанням параарамідних та поліетиленових ниток. Одержані у даній роботі результати для тканих структур не можуть бути трансформовані на трикотажні структури, оскільки це інша технологія формування та спосіб структуроутворення текстильного матеріалу.

Автором іншої роботи [7] досліджено характеристики параарамідних ниток різних виробників вітчизняного та зарубіжного виробництва, зокрема їх питоме розривальне навантаження та видовження після дії на сировину різноманітних чинників, пов'язаних з експлуатацією виробів 3 них: навколишнє середовище, кінетика сорбції, десорбції водяної пари, кінетика набухання у воді. Це дає можливість оцінити поведінку ниток за різних умов експлуатації. Автором встановлено основні недоліки арамідних волокон: низький опір стискуючим навантаженням і порівняно високе вологопоглинання. Введення в їх структуру високомодульних керамічних та скляних волокон дозволяє зберегти електрофізичні властивості та підвищити міцність при стисненні. Однак, описані у даній роботі результати досліджень стосуються виключно ниток до етапу їх переробки у текстильний матеріал (тканину чи трикотаж). Тобто не враховані процеси та переходи нитки на устаткуванні, що також впливає на втрату міцності нитки.

Робота [8] присвячена вивченню впливу умов розриву параарамідних ниток різних виробників російського та зарубіжного виробництва на їх розривальні характеристики, а саме у мокрому та сухому стані, у вигляді прямолінійного відрізка, з імітацією петлі та вузла. Цей метод дозволяє дати оцінку неоднорідності структури ниток різного асортименту, виявити зміни, що відбуваються в нитках при переробці у текстильний матеріал. Результатом роботи є падіння міцності і приріст подовження при розриві, що спостерігаються внаслідок прояву ефекту пластифікації. Аналогічно попередній роботі [7], автором проведено дослідження на нитках до їх переробки у текстильний матеріал.

У роботі [9] автором проведені випробування з визначення механічних властивостей ниток в залежності від швидкості руху затискача розривної машини. У якості об'єкта дослідження використано параарамідні нитки вітчизняного та зарубіжного виробництва. Залежно від швидкості розтягування змінюється час, протягом якого здійснюється деформація, при збільшенні швидкості час деформування знижується. Внаслідок цього не вистачає часу зруйнуватися більшості міжмолекулярних зв'язків, розвинутися еластичній і пластичній деформації. При низькій швидкості виходить зворотна залежність: зі збільшенням швидкості розтягування розривальне навантаження зростає, а розривальне видовження зменшується.

Таким чином, аналіз наукових публікацій вітчизняних та зарубіжних авторів, які працюють у сфері дослідження поведінки надміцної сировини під впливом різноманітних чинників, дозволяє зробити висновок, що данні результати не дають вичерпних відомостей про поведінку ниток у разі їх переробки на в'язальному обладнанні. Отже, питання впливу властивостей виду надміцної сировини та 
особливостей протікання технологічних процесів виробництва на показники втрати їі міцності та фізикомеханічні характеристики одинарного кулірного трикотажу переплетення гладь вивчено недостатньо та потребує проведення додаткових досліджень.

\section{Формулювання мети дослідження}

Метою даної роботи є дослідження впливу типу в'язального обладнання та введення у структуру металевої мононитки на показники втрати міцності високомолекулярних поліетиленових та параарамідних ниток при їх переробці в структуру кулірного трикотажу переплетення гладь.

\section{Викладення основного матеріалу дослідження}

При створенні текстилю підвищеної міцності важливо розуміти як саме впливає безпосередньо процес в'язання трикотажу на втрату міцності вихідної сировини. У даному дослідженні зразки трикотажних полотен вироблено одинарним кулірним переплетенням гладь, 3 двох видів сировини: високомолекулярних поліетиленових (ПЕ) та параарамідних (ПА) ниток. Для підвищення міцності трикотажу додатково у структуру вв'язано металеву мононитку. Для виготовлення дослідних зразків трикотажу використано два типи плосков'язального обладнання 8 класу: плоскофангову машину типу ПВРК та рукавичний автомат ПА-8-33 (РА). При цьому довжина нитки в петлі на двох типах в'язального обладнання залишалась незмінною $(\ell=8,9 \mathrm{Mm})$. Заправні дані дослідних зразків наведено у табл. 1.

Таблиця 1

Параметри структури дослідних зразків трикотажу

\begin{tabular}{|c|c|c|c|c|c|}
\hline $\begin{array}{c}\text { № } \\
\text { зразка }\end{array}$ & $\begin{array}{c}\text { Тип } \\
\text { в'язального } \\
\text { обладнання }\end{array}$ & $\begin{array}{c}\text { Вид } \\
\text { сировини }\end{array}$ & $\begin{array}{c}\text { Лінійна } \\
\text { густина, текс }\end{array}$ & $\begin{array}{c}\text { Товщина, } \\
\text { мм }\end{array}$ & $\begin{array}{l}\text { Поверхнева } \\
\text { густина, г/м² }\end{array}$ \\
\hline 1 & \multirow{4}{*}{ ПВРК } & $\Pi \mathrm{E}$ & $44 X 2$ & 0,80 & 177,9 \\
\hline 2 & & ПА & 92 & 0,70 & 192,5 \\
\hline 3 & & $\begin{array}{c}\text { ПЕ } \\
\text { металева нитка }\end{array}$ & $\begin{array}{c}44 X 2 \\
0,12 \mathrm{~mm}\end{array}$ & 0,85 & 304,2 \\
\hline 4 & & $\begin{array}{c}\text { ПА } \\
\text { металева нитка }\end{array}$ & $\begin{array}{c}92 \\
0,12 \mathrm{Mм}\end{array}$ & 0,79 & 312,0 \\
\hline 5 & \multirow{4}{*}{ PA } & ПЕ & $44 \times 2$ & 1,10 & 191,0 \\
\hline 6 & & ПА & 92 & 1,00 & 196,0 \\
\hline 7 & & $\begin{array}{c}\text { ПЕ } \\
\text { металева нитка }\end{array}$ & $\begin{array}{c}44 X 2 \\
0,12 \mathrm{~mm}\end{array}$ & 1,20 & 306,8 \\
\hline 8 & & $\begin{array}{c}\text { ПА } \\
\text { металева нитка }\end{array}$ & $\begin{array}{c}92 \\
0,12 \mathrm{Mм}\end{array}$ & 1,12 & 323,7 \\
\hline
\end{tabular}

На обраних двох типах плосков'язального обладнання реалізується в'язальний послідовний процес петлетворення. Відмінність полягає у тому, що на плоскофанговій машині типу ПВРК у ході в'язання трикотаж знаходиться під впливом значного зусилля відтягування, яке за прикладеною силою $\epsilon$ загальним, а на рукавичному автоматі операція відтягування забезпечується горловинами платин (зосереджене відтягування). У ході переробки параарамідних ниток на рукавичному автоматі внаслідок їх значної жорсткості зусилля відтягування полотна виявилося недостатнім. Через це на полотні формувалися витягнуті пресові петлі. Для забезпечення нормального перебігу процесу петлетворення створено додаткове зусилля відтягування полотна шляхом використання тягарців сумарною вагою 596 г. При цьому довжина нитки в петлі залишалась незмінною.

Для визначення розривального навантаження та розривального видовження нитки після в'язання на розривній машині КаоTieh KT-7010AZ у відповідності до існуючої стандартизованої методики [10] шляхом розпуску вироблених зразків трикотажу підготовлено по 10 дослідних проб у вигляді відрізків ниток затискної довжини 500 мм (загальна довжина 700 мм). Результати розрахунку середніх значень розривального навантаження та розривального видовження ниток після в'язання та показник втрати міцності нитки наведено у табл. 2.

Коефіцієнт використання міцності представляє собою відношення величини розривального навантаження після в'язання до величини розривального навантаження вихідної ниткир [1]. Для співставлення розривального навантаження двох видів сировини, які відрізняються за лінійною густиною, величину розривального навантаження приведено до одиниці лінійної густини нитки. Величина питомого розривального навантаження / видовження вихідної сировини до в'язання: ПЕ ниток складає 198,59 г/текс / 6,08\%, ПА ниток - 161,98 г/текс / 4,96\%.

Для того щоб з'ясувати, який вплив на розривні характеристики поліетиленових та параарамідних ниток здійснює тип в'язального обладнання та введення у структуру металевої мононитки, нами проведено порівняльний аналіз одержаних результатів експериментальних досліджень. 
На підставі даних табл. 2 побудовано діаграми (рис.1-3), які наглядно ілюструють вплив зміни виду сировини та типу в'язального обладнання на вищезазначені характеристики.

Таблиця 2

Механічні характеристики дослідних зразків

\begin{tabular}{|c|c|c|c|}
\hline $\begin{array}{c}\text { № } \\
\text { зразка }\end{array}$ & $\begin{array}{c}\text { Розривальне } \\
\text { навантаження, г/текс }\end{array}$ & $\begin{array}{c}\text { Розривальне } \\
\text { видовження, } \%\end{array}$ & $\begin{array}{c}\text { Коефіцієнт використання } \\
\text { міцності }\end{array}$ \\
\hline 1 & 171,74 & 9,52 & 0,86 \\
\hline 2 & 159,84 & 4,70 & 0,99 \\
\hline 3 & 129,73 & 7,32 & 0,65 \\
\hline 4 & 154,34 & 4,58 & 0,95 \\
\hline 5 & 177,06 & 10,16 & 0,89 \\
\hline 6 & 155,54 & 4,26 & 0,96 \\
\hline 7 & 47,35 & 7,78 & 0,24 \\
\hline 8 & 151,23 & 4,24 & 0,93 \\
\hline
\end{tabular}

3 діаграм, наведених на рис.1, видно, що величина розривального навантаження обох ниток після в'язання порівняно 3 вихідною сировиною зменшується. Але при цьому на втрату міцності досліджуваних ниток має вплив як тип в'язального обладнання, так і вв'язування у структуру трикотажу металевої мононитки. Величина розривального навантаження ПЕ нитки після в'язання трикотажу на рукавичному автоматі (зразок5) більша порівняно з трикотажем, виробленим на машині ПВРК (зразок 1) на3,1\%. Разом з тим величина розривального навантаження ПА нитки після в'язання зразка 6 (РА) порівняно зі зразком 2 (ПВРК) менша на 2,7\%. Порівняно 3 вихідною сировиною розривальне навантаження ПЕ нитки після в'язання зразка 1 на машині ПВРК знизилось на 13,2\%; зразка 5, виробленого на рукавичному автоматі, - на 10,5\%. Розривальне навантаження ПА нитки після в'язання зразка 2 порівняно з вихідною сировиною знизилось лише на 1,3\%, зразка 6 - на 3,98\% (рис. 1, а).
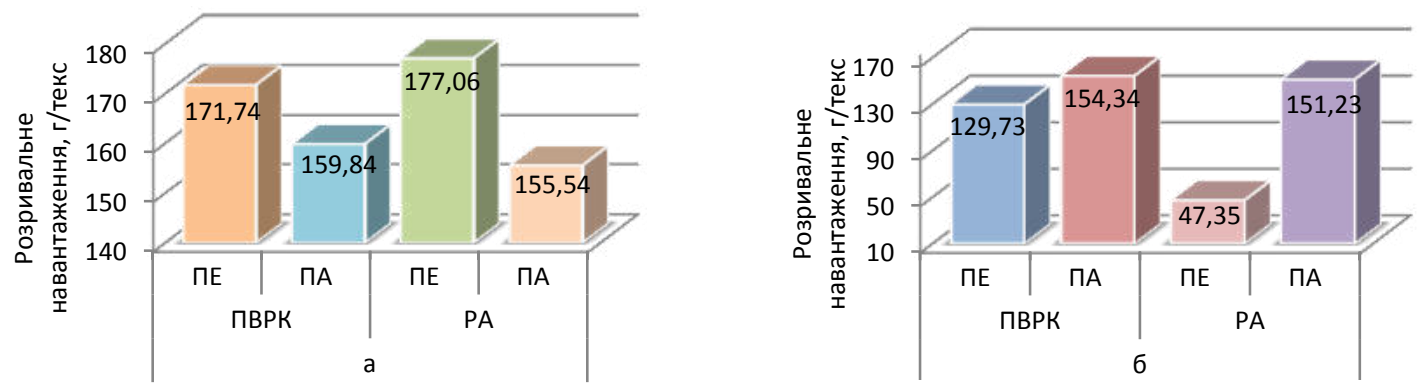

Рис. 1. Діаграми розривального навантаження поліетиленової

та параарамідної ниток після в'язання трикотажу:

а- без металевої мононитки, б- 3 металевою монониткою

Найбільший вплив на зниження рівня розривального навантаження нитки у разі поєднання у процесі в'язання трикотажу ПЕ ниток 3 металевою монониткою на рукавичному автоматі. Це пояснюється участю у процесі в'язання трикотажу платин, які своїми горловинами створюють зосереджену на платинних дугах петель взаємодію двох ниток. Зміна типу в*8язального обладнання 3 ПВРК на РА призводить до зниження величини розривального навантаження ПЕ нитки після в'язання трикотажу (зразок 7 порівняно зі зразком 3) на 63,48\%. На величину розривального навантаження ПА нитки при її поєднанні у процесі в'язання з металевою монониткою тип в'язального обладнання впливає у незначній міні (зразок 8 порівняно зі зразком 4), а саме: знижується на 2,02\% (рис.1, б).

Діаграми, представлені на рис. 2, наглядно ілюструють вплив типу в'язального обладнання та введення у структуру трикотажу металевої мононитки на величину розривального видовження ПЕ та ПА ниток після в'язання. Слід зауважити, що розривальне видовження ПА нитки після в'язання порівняно 3 вихідною сировиною зменшується, а ПЕ нитки - збільшується, а саме: зразка 2 зменшується на 5,24\%; зразка 5 - на 14, 11\%, зразка 4 - на 7,66\%, зразка 8 - на 14,52\%; зразка 1 зростає на 56,6\%, зразка 5 - на $67,0 \%$, зразка 3 - на 20,4\% зразка 7 - на 27,96\%. При цьому вв'язування у структуру трикотажу металевої мононитки призводить до зниження рівня розривального видовження обох видів ниток, що можна пояснити перерозподілом навантаження у процесі в'язання трикотажу між нитками, які пров'язані у петлі (ПА чи ПЕ ниткою та металевою монониткою). Крім того, у разі вироблення дослідних зразків трикотажу з ПЕ нитки на рукавичному автоматі величина розривального видовження нитки після в'язання вища порівняно зі зразками з машини ПВРК. Зміна типу в'язального обладнання з РА на ПВРК у 
випадку використання ПА нитки навпаки призводить до зростання розривального видовження. Більш чутливою до впливу процесу в'язання на величину розривального видовження виявилася ПЕ нитка.
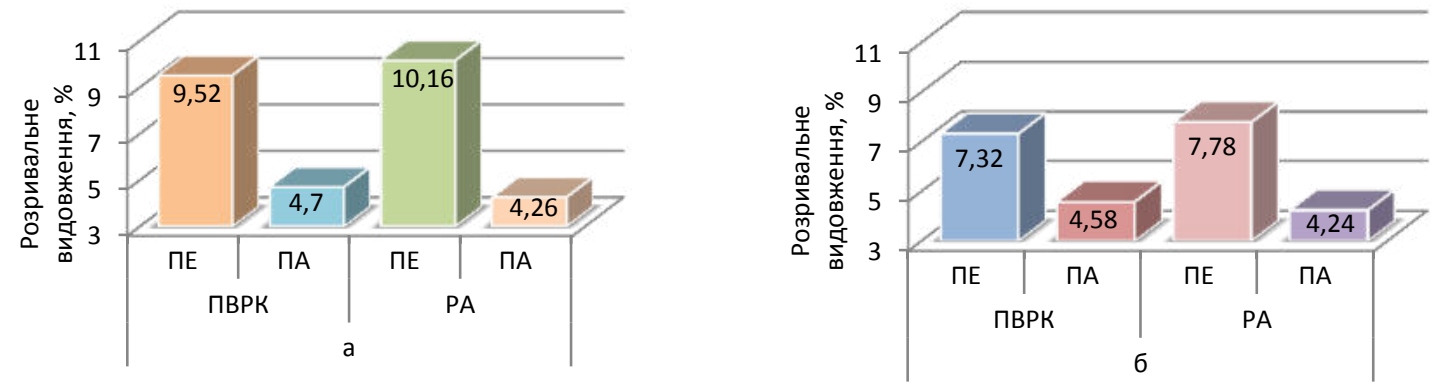

Рис. 2. Діаграми розривального видовження поліетиленової та параарамідної ниток після в'язання трикотажу:

а- без металевої мононитки, б- 3 металевою монониткою

Діаграми, представлені на рис. 3, наглядно ілюструють як в межах одного типу в'язального обладнання змінюється показник втрати міцності поліетиленової та параарамідної ниток (рис.3, а), а також у разі поєднання їх у процесі в’язання з металевою монониткою (рис.3, б).
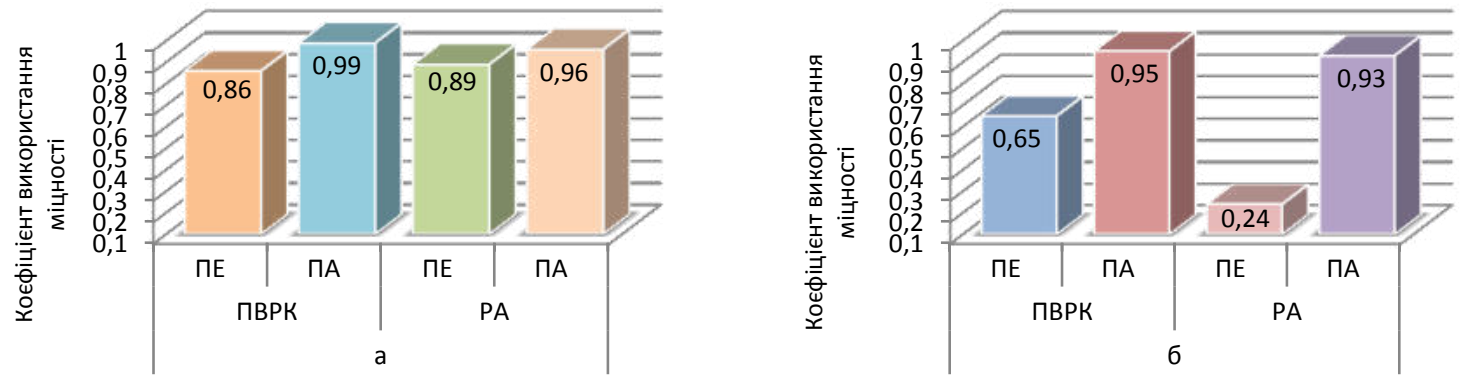

Рис. 3. Діаграми використання міцності поліетиленової

та параарамідної ниток у процесі в'язання трикотажу:

а- без металевої мононитки, б- 3 металевою монониткою

У результаті реалізованого експерименту виявлено, що ПА нитки у процесі їх переробки на в'язальному обладнанні порівняно з ПЕ нитками менш схильні до втрати міцності. Їх поєднання у процесі в'язання з металевою монониткою також у незначній мірі впливає на втрату ії міцності. Значення коефіцієнта використання міцності ПЕ нитки, поєднаної у процесі в'язання з металевою монониткою (зразки 3,7$)$, дозволили зробити висновок щодо впливу особливостей процесу в'язання (типу в'язального обладнання) на втрату іiі міцності після в'язання. Так ПЕ нитка зразка 3 порівняно з вихідною сировиною втратила свою міцність на $35 \%$, зразка 7 - на 76\%. При цьому зміна типу в'язального обладнання з ПВРК на РА призвела до зниження коефіцієнта використання міцності у 2,7 рази.

\section{Висновки}

У ході проведених досліджень встановлено що за величиною розривального навантаження після в'язання на одиницю лінійної густини поліетиленова нитка показала кращі результати. Але при цьому у разі вироблення дослідних зразків на рукавичковому автоматі з введенням у структуру металевої мононитки поліетиленова нитка втрачає свою міцність на 76\% (зразок 7). Це пов'язано з особливостями протікання процесу петлетворення та будовою нитки, яка представляє собою багатофіламентну не кручену нитку. Саме наявність великої кількості філаментів та відсутність крутки призводить до більшої iii руйнації порівняно 3 параарамідною ниткою при взаємодії з металевою монониткою у процесі виконання зосередженого зусилля відтягування за допомогою платин.

У процесі переробки на в’язальному обладнанні поліетиленова нитка внаслідок особливостей будови вихідного полімеру стає більш податливою до розривального видовження, у порівнянні 3 параарамідною ниткою. При цьому розривальне видовження параарамідних ниток після їх переробки у структуру трикотажу навіть зменшується порівняно з вихідною сировиною. Це можна пояснити тим, що у процесі в’язання під дією зусилля відтягування відбувається розпрямлення та паралелізація елементарних волокон в структурі комплексної нитки, внаслідок чого і зменшується розривальне видовження. 
Коефіцієнт використання міцності нитки є основним показником, який вказує на втрату міцності нитки у процесі в'язання. У результаті реалізованого експерименту виявлено, що коефіцієнт використання міцності параарамідної нитки зразків трикотажу без введення у структуру металевої мононитки, порівняно з поліетиленовою, незалежно від типу в'язального обладнання має вищі значення. Таким чином поліетиленові нитки при переробці їх у структуру трикотажу переплетення гладь у більшій мірі втрачають міцність, що пояснюється особливостями вихідного полімера. Поліетиленові нитки більш чутливі до видовження при силових навантаженнях. Це і спричиняє їх більшу втрату міцності у процесі в'язання трикотажу.

\section{Список використаної літератури}

1. Безсмертна В. I. Дослідження впливу типу плосков'язального обладнання на втрату міцності надмолекулярної поліетиленової нитки після в'язання / В.І. Безсмертна, С.В. Офіцерова, Л.Є. Галавська // Молодь - науці і виробництву - 2018: Інноваційні технології легкої промисловості : матеріали міжнародної науково-практичної конференції здобувачів вищої освіти і молодих учених, м. Херсон, 17-18 травня 2018 року. - Херсон : ХНТУ, 2018. - С. 36-39.

2. Дмитрик О.М. Дослідження впливу типу плосков'язального обладнання на втрату міцності параарамідних ниток після в'язання / О.М. Дмитрик, Л.С. Галавська // Молодь - науці і виробництву - 2019: Інноваційні технології легкої промисловості : матеріали міжнародної науково-практичної конференції здобувачів вищої освіти і молодих учених, м. Херсон, 16-17 травня 2019 року. - Херсон: ХНТУ, 2019. - С. 49-51.

3. Дмитрик О.М. Дослідження впливу виду надміцної сировини на показники втрати міцності після в'язання / О.М. Дмитрик, В.І. Безсмертна, Л.С. Галавська // Збірник матеріалів III Міжнародної науково-практичної конференції текстильних та фешн технологій KуivTex\&Fashion / за заг. ред. Л.І. Зубкової: (31 жовтня 2019 р., м. Київ). - Київ: КНУТД, 2019. - С. 257-261.

4. Боброва С. Ю. Вплив параметрів в'язання на структурні характеристики трикотажу, виготовленого 3 високомолекулярних поліетиленових ниток / С.Ю. Боброва, Л.Є. Галавська, Л. А. Синькова // Вісник Херсонського національного технічного університету. - 2018. - № 4 (67) . - С. 133-138.

5. Безсмертна В.І. Дослідження втрати міцності параарамідних ниток у процесі в'язання кулірного трикотажу / В.І. Безсмертна, Л.С. Галавська, С.Ю. Боброва // Вісник Київського національного університету технологій та дизайну. - 2019. - №2 (132). - С. 51-59.

6. Беляєва Є.О. Слоистые органокомпозиты и гибридные композиты на основе волокон из сверхвысокомолекулярного полиэтилена: дис. ... канд. тех. наук: 05.17.06 - Технология и переработка полимеров и композитов, 02.00.04 - «Физическая химия» / Москва - 2019. - 165 с.

7. Лебедева Н.П. Влияние эксплуатационных воздействий на свойства параарамидных нитей технического назначения: автореф. дис. ... канд. тех. наук: специальность 05.19 .01 «Материаловедение производств текстильной и легкой промышленности» / Лебедева Наталья Павловна - Санкт-Петербург - 2007. - 17 с.

8. Глобина С.А. Исследование прочности в сухом и мокром состоянии параарамидных нитей российского и зарубежного производства / С.А. Глобина, А.В. Курденкова, Ю.С. Шустов, Я.И. Буланов // Вестник науки и образования. - 2018. - №7 (43). - С. 27-32.

9. Глобина С.А. Исследование влияния скорости растяжения на механические свойства параарамидных нитей / С.А. Глобина, А.В. Курденкова, Ю.С. Шустов, Я.И. Буланов // Вестник науки и образования № 7(43) 2018. Том 2 - С. 23-26.

10. ДСТУ ISO 2062:2015. Текстиль. Пряжа з пакувань. Визначення розривального навантаження та видовження під час розриву (ISO 2062:2009, IDT).

\section{References}

1. $\quad$ Bezsmertna V.I., Ofitserova S.V., Halavska L.Ie. Doslidzhennja vplyvu typu ploskov'jazaljnogho obladnannja na vtratu micnosti nadmolekuljarnoji polietylenovoji nytky pislja v'jazannja. konf. «Molodj - nauci i vyrobnyctvu 2018: Innovacijni tekhnologhiji leghkoji promyslovosti» [Materialy mizhnarodnoji naukovo-praktychnoji konferenciji zdobuvachiv vyshhoji osvity i molodykh uchenykh]. Kherson, 17-18 travnia 2018, pp. 36-39.

2. Dmytryk O.M., Halavska L.Ie. Doslidzhennia vplyvu typu ploskoviazalnoho obladnannia na vtratu mitsnosti paraaramidnykh nytok pislia viazannia. konf. «Molodj - nauci i vyrobnyctvu - 2019: Innovacijni tekhnologhiji leghkoji promyslovosti» [Materialy mizhnarodnoji naukovo-praktychnoji konferenciji zdobuvachiv vyshhoji osvity i molodykh uchenykh]. Kherson, 16-17 travnia 2019, pp. 4951.

3. Dmytryk O.M., Bezsmertna V.I., Halavska L.Ie. Doslidzhennja vplyvu vydu nadmicnoji syrovyny na pokaznyky vtraty micnosti pislja v'jazannja. konf. «III Mizhnarodna naukovo-praktychna konferentsiia tekstylnykh ta feshn tekhnolohii KyivTex\&Fashion» [Zbirnyk materialiv za zah. red. L.I. Zubkovoi]. Kyiv, 31 zhovtnia 2019, pp. 257-261. 
4. Bobrova S. Yu., Halavska L.Ie., Synkova L. A. Vplyv parametriv v'jazannja na strukturni kharakterystyky trykotazhu, vyghotovlenogho z vysokomolekuljarnykh polietylenovykh nytok. Visnyk Khersonsjkogho nacionaljnogho tekhnichnogho universytetu, 2018, no. 4 (67), pp. 133-138.

5. Bezsmertna V.I., Halavska L.Ie., Bobrova S.Iu. Doslidzhennia vtraty mitsnosti paraaramidnykh nytok u protsesi viazannia kulirnoho trykotazhu. Visnyk Kyivskoho natsionalnoho universytetu tekhnolohii ta dyzainu, 2019, no. №2 (132), pp. 51-59.

6. Beliaieva Ye.O. Sloystыe orhanokompozytы y hybrydnye kompozyty na osnove volokon yz sverkhvysokomolekuliarnoho polyetylena. Diss. kand. techn. nauk [05.17.06 - Tekhnolohyia y pererabotka polymerov y kompozytov, 02.00.04 - Fyzycheskaia khymyia]. Moskva, 2019. 165 P.

7. Lebedeva N.P. Vlyianye эkspluatatsyonnыkh vozdeistvyi na svoistva paraaramydnыkh nytei tekhnycheskoho naznachenyia: avtoref. Diss. kand. techn. nauk [05.19.01 - Materyalovedenye proyzvodstv tekstylnoi y lehkoi prombshlennosty], Sankt-Peterburh, 2007. 17 P.

8. Hlobyna S.A., Kurdenkova A.V., Shustov Yu.S., Bulanov Ya.Y. Issledovanie prochnosti v suhom i mokrom sostoyanii paraaramidnyh nitej rossijskogo i zarubezhnogo proizvodstva. Vestnik nauki i obrazovaniya, 2018, no. (43)., pp. 27-32.

9. Hlobyna S.A., Kurdenkova A.V., Shustov Yu.S., Bulanov Ya.Y. Issledovanie vliyaniya skorosti rastyazheniya na mehanicheskie svojstva paraaramidnyh nitej. Vestnik nauki i obrazovaniya, 2018, no. 7(43), T. 2, pp. 23-26.

10. DSTU ISO 2062:2015. Tekstyl. Priazha z pakuvan. Vyznachennia rozryvalnoho navantazhennia ta vydovzhennia pid chas rozryvu (ISO 2062:2009, IDT). Kyiv, 2015. 12 p. 